\title{
Is Increased Mean Platelet Volume a Risk Factor in Patients with Acute Deep Vein Thrombosis?
}

\author{
Artmış Ortalama Trombosit Hacmi Akuł Derin Ven Trombozlu Hastalarda \\ Bir Risk Faktorü müdür?
}

\author{
Asım KALKAN, ${ }^{1}$ Mehmet Erdem MEMETOĞLU, ${ }^{2}$ Özlem BiLiR, ${ }^{1}$ \\ Gökhan ERSUNAN, ${ }^{1}$ Rasim KUTLU, ${ }^{3}$ Nuri TUTAR ${ }^{4}$

\begin{abstract}
'Department of Emergency Medicine, Recep Tayyip Erdoğan University Faculty of Medicine, Rize; Departments of ${ }^{2}$ Cardiovascular Surgery, ${ }^{3}$ Cardiology, Gümüşhane State Hospital, Gümüşhane;

${ }^{4}$ Department of Thoracic Medicine, Erciyes Univercity Faculty of Medicine, Kayseri, Turkey.
\end{abstract}

\section{SUMMARY \\ Objectives}

The purpose of this retrospective study was to compare the mean platelet volume between the patients with acute deep vein thrombosis (DVT) and control subjects.

\section{Methods}

Data were collected retrospectively from the patients' medical records. The study group consisted of 110 patients with newly diagnosed acute DVT in the lower extremities. An age, gender, and body mass index-matched control group consisted of 98 patients with normal duplex ultrasound findings. We compared the mean platelet volume in patients with acute DVT and control participants.

\section{Results}

There was no significant difference between the study and control groups in mean platelet volume $(8.8 \pm 1.6$ vs $8.7 \pm 1.3 \mathrm{fl}$, respectively; $p>0.05)$. Age $(p=0.899)$, body mass index $(p=0.43)$, gender $(p=0.466)$, and platelet count $(\mathrm{p}=0.886)$ were statistically similar in both groups.

\section{Conclusions}

There was no significant difference in mean platelet volume between patients with acute DVT and the control group. According to our result, we propose that mean platelet volume should not be considered as an index of acute DVT.

Key words: Deep vein thrombosis; mean platelet volume; platelet activation.

\section{ÖZET}

Amaç

Bu retrospektif çalışmanın amacı, ortalama tombosit hacmini, akut derin ven trombozlu (DVT) hastalarda ve kontrol grubunda karşılaştırmaktır.

\section{Gereç ve Yöntem}

Veriler, hastaların tıbbi kayıtlarından geriye dönük olarak elde edildi. Çalışma grubu, yeni teşhis edilmiş alt ekstremite akut DVT'li 110 hastadan oluştu. Yaş, cinsiyet ve vücut kitle oranları karşılaştırılmış kontrol grubu, normal dupleks ultrason bulgulu 98 hastadan oluştu. Ortalama trombosit hacmini, akut DVT'li hastalarda ve kontrol grubunda istatistiksel olarak karşılaştırdık.

\section{Bulgular}

Ortalama trombosit hacmi ( $8.8 \pm 1.6$ ve $8.7 \pm 1.3 \mathrm{fl}$, sirasıyla; $p>0.05)$ bakımından çalışma ve kontrol gruplarında belirgin farklılık izlenmedi. Yaş ( $p=0.899)$, vücut kitle oranı ( $p=0.43)$, cinsiyet $(p=0.466)$ ve trombosit sayısı $(p=0.886)$ her iki grup için istatistiksel olarak benzerdi.

\section{Sonuç}

Ortalama trombosit hacmi yönünden akut DVT'li hastalar ve kontrol grubunda istatistiksel olarak belirgin bir fark yoktu. Bulgularımıza göre, ortalama trombosit hacminin, akut DVT'nin bir göstergesi olmadığını düşünmekteyiz.

Anahtar sözcükler: Derin ven trombozu; ortalama trombosit hacmi; trombosit aktivasyonu. 


\section{Introduction}

Deep vein thrombosis (DVT) is the formation of a blood clot in a deep vein. According to Virchow's triad, venous thrombosis occurs via three mechanisms: decreased flow rate of the blood, damage to the blood vessel wall, and an increased tendency of the blood to clot (hypercoagulability). ${ }^{[1]}$ DVT commonly affects the leg veins, such as the femoral vein or the popliteal vein, or the deep veins of the pelvis. ${ }^{[2]}$ An acute DVT occurs when the thrombosis is present for a duration of less than 14 days. ${ }^{[3]}$

Doppler ultrasonography (US) is a highly sensitive and specific diagnostic tool for the detection of DVT, either acute or chronic, although it is operator dependent. Invasive venography is the gold standard technique for diagnosis. However, doppler US is the prefferred method because it is noninvasive, safe, and inexpensive. ${ }^{[4]}$

Recent advances in automated blood cell analyzers have made it possible to obtain new information about platelets through the measurement of platelet indices, including mean platelet volume (MPV). MPV is an indicator of platelet activation, which has an important role in the pathophysiology of thrombosis. Higher MPV values have been observed in patients with stroke and acute myocardial infarction, unstable angina pectoris, coronary artery ectasia, preeclampsia, and renal artery stenosis compared with control subjects. ${ }^{[5]}$

It has been shown previously that platelet activation occurs in patients with DVT. The purpose of this study is to investigate whether MPV differs in patients with acute DVT compared to control subjects. MPV, a simple and easily obtainable laboratory value that might predict a patient's predilection to develop DVT and/or require prophylaxis for DVT.

\section{Materials and Methods}

The records of consecutive US examinations from December 2010 to December 2011 performed on the lower extremities in the emergency department for a provisional diagnosis of DVT were reviewed retrospectively. The study was carried out according to the principles of Declaration of Helsinki, and local ethical committee approved the study.

A total of 6500 consecutive US examinations were performed during the study period. Of these patients, 5330 (82\%) had normal doppler US findings. 1170 (18\%) patients had DVT. The DVT study group excluded $602(9 \%)$ patients with chronic DVT (symptoms more than 14 days), 101 patients with heart disease (2\%), 203 (3\%) patients having a recent surgical operation or trauma history, $32(0.5 \%)$ patients with renal or hepatic disease, $5(0.08 \%)$ patients with pregnancy, $4(0.06 \%)$ patients with malignant disease, $50(0.8 \%)$ patients with diabetes mellitus, $55(0.8 \%)$ patients having a therapy on lipid lowering drugs, 115 (2\%) patients using antiplatelet agents, $350(5 \%)$ smoking patients, 35 (0.05\%) patients who had stroke, and $20(0.03 \%)$ patients had been given a dose of anticoagulation yet before their blood sample was taken. Among patients with normal US findings, 98 (1\%) healthy individuals were randomly selected to form control group. Finally, the study group consisted of 110 patients (1\%) who had acute DVT.

All US examinations were performed using an Acuson $120 X P 10$ (Aspen, California, USA) device equipped with a $12-\mathrm{MHz}$ linear transducer in the radiology department by US experienced radiologists. Lack of compressibility (the major criterion), increased cross-sectional diameter, heterogeneous intraluminal material, absence of Doppler signal, and collateralization were the diagnostic ultrasound criteria for DVT. Distal (calf vein) and proximal (popliteal, femoral, and iliac) location of the acute DVT was recorded. As part of the routine clinical approach in our emergency service, blood samples were drawn from the antecubital vein with a 20-Gauge needle, and whole blood counts were measured in blood samples, which were collected to dipotassium EDTA tubes before treatment. The following hematological parameters were recorded in all blood samples: platelet count (PLT), and MPV. Complete blood counts including MPV were determined using an autoanalyzer (Beckman Coulter LH 750). Whole-blood cell counting was routinely performed by the following parameters: PLT $\left(10^{9} / \mathrm{L}\right)$, and MPV (fl). The age, gender, and body mass index (BMI) of participants were recorded.

Descriptive statistics were presented as means, standard deviations, and frequency distributions. Categorical data were compared using chi-square test, and continuous data were compared using the Student's t-test. $p$ values smaller than 0.05 were accepted as significant statistically. Results were presented with tables and graphics.

\section{Results}

The clinical and laboratory findings of the study and control groups were summarized in Table 1 .

The patients' mean age for the acute DVT group was 46.2 \pm 15.6 . Mean age for the control group was $45.8 \pm 16.9$. The mean interval between the onset of symptoms and diagnosis of DVT was $3.24( \pm 1.32)$ days.

Proximal DVT was detected in 38 patients, distal DVT was detected in 49 patients, and both proximal and distal DVT were detected in 23 patients in the study group. Age $(p=$ 
Table 1. Demographic, clinical and laboratory characteristics of the study population

\begin{tabular}{|c|c|c|c|c|c|c|c|}
\hline \multirow[t]{2}{*}{ Characteristics } & \multicolumn{3}{|c|}{ Acute DVT group $(n=110)$} & \multicolumn{3}{|c|}{ Control group ( $n=98$ ) } & \multirow[t]{2}{*}{$p$} \\
\hline & Mean \pm SD & $\mathbf{n}$ & $\%$ & Mean \pm SD & $\mathbf{n}$ & $\%$ & \\
\hline Age & $46.2 \pm 15.6$ & & & $45.8 \pm 16.9$ & & & 0.899 \\
\hline \multicolumn{8}{|l|}{ Body mass index } \\
\hline$<18.5$ & & 13 & 11.8 & & 7 & 6.4 & \multirow{4}{*}{0.43} \\
\hline $18.5-23.9$ & & 45 & 40.9 & & 43 & 43.9 & \\
\hline $24-29.9$ & & 45 & 40.9 & & 45 & 45.9 & \\
\hline$>30$ & & 7 & 7.1 & & 3 & 3.1 & \\
\hline \multicolumn{8}{|l|}{ Gender } \\
\hline Male & & 63 & 57.3 & & 61 & 62.2 & \multirow{2}{*}{0.466} \\
\hline Female & & 47 & 42.7 & & 37 & 37.8 & \\
\hline Platelet count (x109) & $253.4 \pm 81.4$ & & & $245.2 \pm 71.2$ & & & 0.886 \\
\hline Mean platelet volume & $8.8 \pm 1.6$ & & & $8.7 \pm 1.3$ & & & 0.782 \\
\hline
\end{tabular}

0.899), BMI $(p=0.43)$, gender $(p=0.466), \operatorname{PLT}(p=0.886$, Fig. 1$)$, and MPV ( $p=0.782$, Fig. 2$)$ were statistically similar in both groups.

\section{Discussion}

MPV is an indicator of platelet activation, which has an important role in the pathophysiology of thrombosis. Large platelets that contain more dense granules are metabolically and enzymatically more active than small platelets and have higher thrombotic potential. Large platelets express higher levels of prothrombotic substances, thromboxane A2, serotonin, b-thromboglobulin, and procoagulatory surface proteins, such as P-selectin and glycoprotein IIla. ${ }^{[6,7]}$ Increased MPV is associated with gestational diabetes mellitus, ${ }^{[8]}$ congestive cardiac failure, ${ }^{[9]}$ hypertension, ${ }^{[10]}$ hypercholesterol-

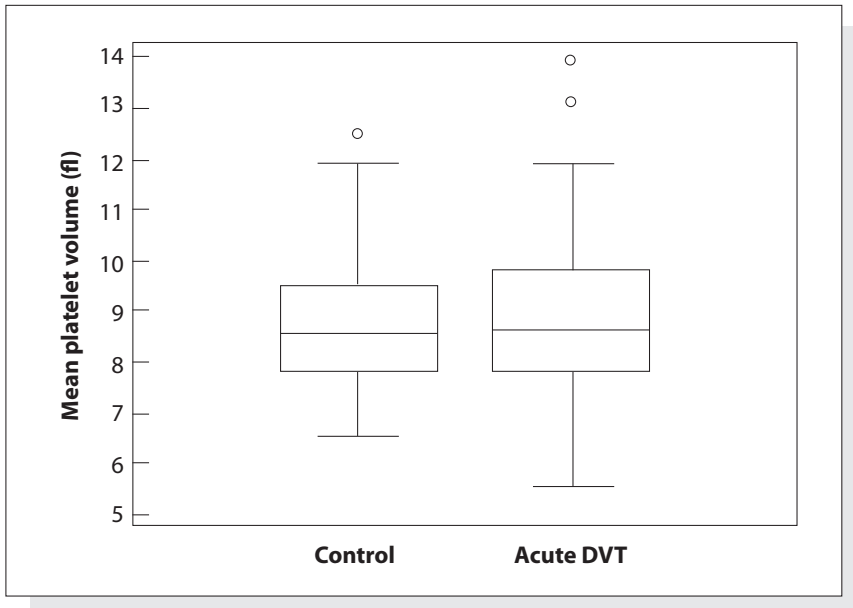

Figure 1. Comparison of both the groups for mean platelet volume. emia ${ }^{[11]}$ and smoking. ${ }^{[12]}$ Therefore, we excluded all patients having and of the above mentioned diseases to reduce the confounding effect in our statistical analysis.

The volume of a thrombocyte varies over a large scale between 2-40 fl, and various factors may influence the volume of a thrombocyte such as thrombocytopenia resulting from platelet loss, or consumption in those with thrombocytopenia secondary to failure of the bone marrow. ${ }^{[13]}$ Megakaryocytes are polyploid cells. They have varying concentrations of DNA within the nucleus and they are capable of changing the relative distribution of DNA concentration. An increase in platelet volume has been shown to be associated with increase in the DNA concentration of megakaryocytes. ${ }^{[13,14]}$

Platelet counts tend to be lower and mean platelet vol-

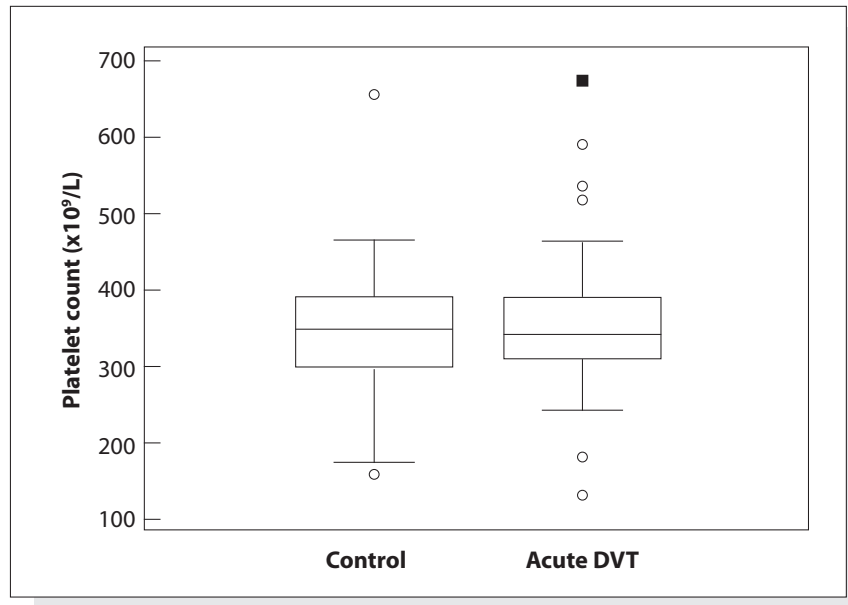

Figure 2. Comparison of both the groups for platelet count. 
umes are higher in patients with myocardial infarction (MI) due to an increase in the production of large, hyperaggregable platelets by the bone marrow or increased platelet consumption at the site of infarction. ${ }^{[15]}$ Thus, it is largely accepted that MPV is an independent risk factor for the first ${ }^{[16]}$ and recurrent MI. ${ }^{[17]}$ Although 3 major parameters have been postulated as determinants of platelet volume, including age dependent processes that can modify platelet size in the circulation, heterogeneity and maturity of the bone marrow megakaryocyte population, and peripheral size related sequestration of platelets in storage pools, ${ }^{[18]}$ there is evidence that MPV is largely determined at or before the time of megakaryocyte fragmentation into platelets. ${ }^{[19]}$

On the other hand, several previous studies revealed that mean MPV was larger in arterial and venous thrombosis and predicted a poor clinical outcome. It has been suggested that MPV is a risk factor for thrombosis. ${ }^{[20,21]}$

Braekkan et al. ${ }^{[22]}$ stated that MPV is a risk factor for venous thromboembolism, and increasing MPV is associated with increased risk of total venous thromboembolism in their prospective, population-based study consisting of 25,923 participants. Acikgoz et al. ${ }^{[23]}$ reported that the presence of thrombosis is associated with higher MPV in Behçet's disease patients, and the increase in MPV is independent of the disease activity.

In our study, we could find no significant change in MPV and PLT in patients with acute DVT compared to controls. Results of our study contradict studies above that have reported an increase in MPV in patients with thrombosis. This contradiction may be explained by the fact that our study group consisted of patients with DVT at the acute stage. We think that increased MPV might be a consequence, rather than a cause, of thrombosis.

This study has several limitations. It is based on the retrospective analysis of a database and we are unable to account for the influence of any residual unmeasured factors that could affect platelet indices. Although the number of our study population is limited in size, as far as we know, this is the first study to evaluate platelet size in acute DVT.

In conclusion, we have shown that MPV was not statistically different in patients with acute DVT compared to control participants. We suggest that MPV is not a risk factor for DVT at the acute stage.

\section{Conflict of Interest}

The authors declares no conflict of interest related to this work.

\section{References}

1. Dickson BC. Virchow's triad. Br J Haematol 2009;145:433.

2. Johnson SA, Stevens SM, Woller SC, Lake E, Donadini M, Cheng J, et al. Risk of deep vein thrombosis following a single negative whole-leg compression ultrasound:a systematic review and meta-analysis. JAMA 2010;303:438-45.

3. Rao AS, Konig G, Leers SA, Cho J, Rhee RY, Makaroun MS, et al. Pharmacomechanical thrombectomy for iliofemoral deep vein thrombosis: an alternative in patients with contraindications to thrombolysis. J Vasc Surg 2009;50:1092-8.

4. Cay N, Ipek A, Gumus M, Birkan Z, Ozmen E. Platelet activity indices in patients with deep vein thrombosis. Clin Appl Thromb Hemost 2012;18:206-10.

5. Sen N, Tavil Y, Yazici HU, Hizal F, Açikgöz SK, Abaci A, et al. Mean platelet volume in patients with coronary artery ectasia. Med Sci Monit 2007;13:CR356-9.

6. Kamath S, Blann AD, Lip GY. Platelet activation: assessment and quantification. Eur Heart J 2001;22:1561-71.

7. Giles H, Smith RE, Martin JF. Platelet glycoprotein Ilb-IIla and size are increased in acute myocardial infarction. Eur J Clin Invest 1994;24:69-72.

8. Hekimsoy Z, Payzin B, Ornek T, Kandoğan G. Mean platelet volume in type 2 diabetic patients. J Diabetes Complications 2004;18:173-6.

9. Chung I, Choudhury A, Lip GY. Platelet activation in acute, decompensated congestive heart failure. Thromb Res 2007; 120:709-13.

10. Coban E, Yazicioglu G, Berkant Avci A, Akcit F. The mean platelet volume in patients with essential and white coat hypertension. Platelets 2005;16:435-8.

11. Pathansali R, Smith N, Bath P. Altered megakaryocyte-platelet haemostatic axis in hypercholesterolaemia. Platelets 2001;12:292-7.

12. Kario K, Matsuo T, Nakao K. Cigarette smoking increases the mean platelet volume in elderly patients with risk factors for atherosclerosis. Clin Lab Haematol 1992;14:281-7.

13. Cameron HA, Phillips R, Ibbotson RM, Carson PH. Platelet size in myocardial infarction. Br Med J 1983;287: 449-51.

14. Martin JF, Plumb J, Kilbey RS, Kishk YT. Changes in volume and density of platelets in myocardial infarction. Br Med J 1983;287:456-9.

15. Pizzulli L, Yang A, Martin JF, Lüderitz B. Changes in platelet size and count in unstable angina compared to stable angina or noncardiac chest pain. Eur Heart J 1998;19:80-4.

16. Endler G, Klimesch A, Sunder-Plassmann $H$, Schillinger $M$, Exner M, Mannhalter $C$, et al. Mean platelet volume is an independent risk factor for myocardial infarction but not for coronary artery disease. Br J Haematol 2002;117:399-404.

17. Burr ML, Holliday RM, Fehily AM, Whitehead PJ. Hematological prognostic indices after myocardial infarction: evidence from the diet and reinfarction trial (DART). Eur Heart J 1992;13:16670.

18. Jackson SR, Carter JM. Platelet volume: Laboratory measurement and clinical application. Blood Reviews 1993;7:104-13. 
19. Thompson CB, Love DG, Quinn PG, Valeri CR. Platelet size does not correlate with platelet age. Blood 1983;62:487-94.

20. Gasparyan AY, Ayvazyan L, Mikhailidis DP, Kitas GD. Mean platelet volume: a link between thrombosis and inflammation? Curr Pharm Des 2011;17:47-58.

21. Ha SI, Choi DH, Ki YJ, Yang JS, Park G, Chung JW, et al. Stroke prediction using mean platelet volume in patients with atrial fibrillation. Platelets 2011;22:408-14.
22. Braekkan SK, Mathiesen EB, Njølstad I, Wilsgaard T, Størmer $\mathrm{J}$, Hansen JB.Mean platelet volume is a risk factor for venous thromboembolism: the Tromsø Study, Tromsø, Norway. J Thromb Haemost 2010;8:157-62.

23. Acikgoz N, Karincaoglu Y, Ermis N, Yagmur J, Atas H, Kurtoglu $\mathrm{E}$, et al. Increased mean platelet volume in Behçet's disease with thrombotic tendency. Tohoku J Exp Med 2010;221:11923. 